\title{
Religiosity of Cirebonese Society Culture in the Oral Tradition Pepujian
}

\author{
Muhammad Kamaluddin \\ Muhammadiyah University of Cirebon \\ enceque_kedawung@yahoo.com
}

\begin{abstract}
Cirebonese society and its culture grew and developed from the long history of the oldest Islamic Sultanate in West Java led by Sunan Gunung Jati. As the king of the Sultanate and at the same time as Waliyullah, various forms of traditional cultural expression held as citizens. One of them is the oral tradition pepujian. This research was conducted as a study of the oral tradition pepujian associated to culture of the people. Linkages which is the idea of semiotic Claude Levi-Strauss (1904) in the study of anthropology and language approach. The methodology used the paradigm of qualitative research. Through the framework of linguistic anthropology, the researcher involved in community activities as part of them. Until finally discovered that the oral tradition pepujian in the culture of the Cirebon community is a poem that contains the Islamic doctrine of faith and worship. This they uttered through the songs as an expression of religiosity.
\end{abstract}

Keywords: Cirebon Society, culture, oral traditions, religiosity

\section{INTRODUCTION}

The study to review the connection between language and culture had previously been done by Ilić (2004). In addition, research on language and religion even before this been done by some scholars. Three of so many researchers were Keane (1997) as well as Darquennes and Vandenbussche (2011). About the study were found to discuss the semiotic relation to culture and society is what has been published by Backer (2007) and Berger (2014).

This paper is the study of the poems in Cirebon language that called pepujian. A culture of oral tradition that grew and developed by generations in the midst of a pluralistic society. Up over time, the oral tradition is also now considered a culture of Cirebonese religious communities. Religiosity is shown through a series of verses of poem containing the teachings of Islamic faith and worship.

To say that culture is communication means to see it as a system of signs. This is the semiotic theory of culture. In its most basic version, this view holds that culture is a representation of the world, a way of making sense of reality by objectifying it in stories, myths, descriptions, theories, proverbs, artistic products and performances. In this perspective, people's cultural products, e.g: myths, rituals, classification of the natural and social world, can also be seen as examples of the appropriation of nature by humans through their ability to establish symbolic relationships among individuals, groups, or species (Duranti, 1997, p. 33).

In the other hand, the science of signs is semiotics, a sign being anything that can be used to stand for something else.
There are two "founding fathers" of semiotics, the Swiss linguist Ferdinand de Saussure and the American philosopher Charles Sanders Peirce. Saussure divided signs into two parts: every sign is made of sound-images or signifiers and the concepts generated by the signifiers, signifieds. Peirce explained that there are three kinds of signs: icons, indexes, and symbols. Icons signify by resemblance, indexes signify by cause and effect, and symbols signify on the basis of convention (Berger, 2014, pp. 22-23).

Regarding this linguistic discipline, it should be noted that the link between linguistics and anthropology dates back to the structuralism of Ferdinand de Saussure, which laid the basis for a new approach in sociology and anthropology. Also influential was de Saussure's idea of language as a system of mutually defining entities and, especially, his theory of meaning with the notions of signifier, signified, and sign, where meaning is not accorded by a simple correspondence of a sign to an external object, but by the relation of the sign to the whole code of signification (Ilić, 2004, p. 4).

Therefore the structuralist anthropologist Claude LéviStrauss who found the earliest examples of the view of culture as communication suggested that not just language, but culture itself could be looked upon as a code of meaning in de Saussure's sense. According to him, all cultures are sign systems that express deeply cognitive predispositions to categorize the world in terms of binary oppositions (Duranti 1997, Ilić 2004).

For instance of binary oppositions are shown by the words "inside" and "outside" words, batin and lair (terms borrowed, as a matter of fact, from the sufi tradition of Muslim mysticisme, but locally reworked) refer on the one hand to the felt realm of human experience and on the other to the observed realm of human behaviour (Geertz, 1983, p. 60).

In the other hand, signs stand in for or represent concepts and can be understood as marks and noises that generate or carry meaning through their relationship with other signs. The study of signs and the way they work is the domain of semiotics wherein the components of a sign are called the signifier and signified (Barker, 2004, p.183).

Signs may stand for something to somebody, who will be called the interpreter. But a sign only functions as such to the interpreter in virtue of interpreter's understanding that does so function, and this understanding is called interpretant. An example is given in the figure below. 


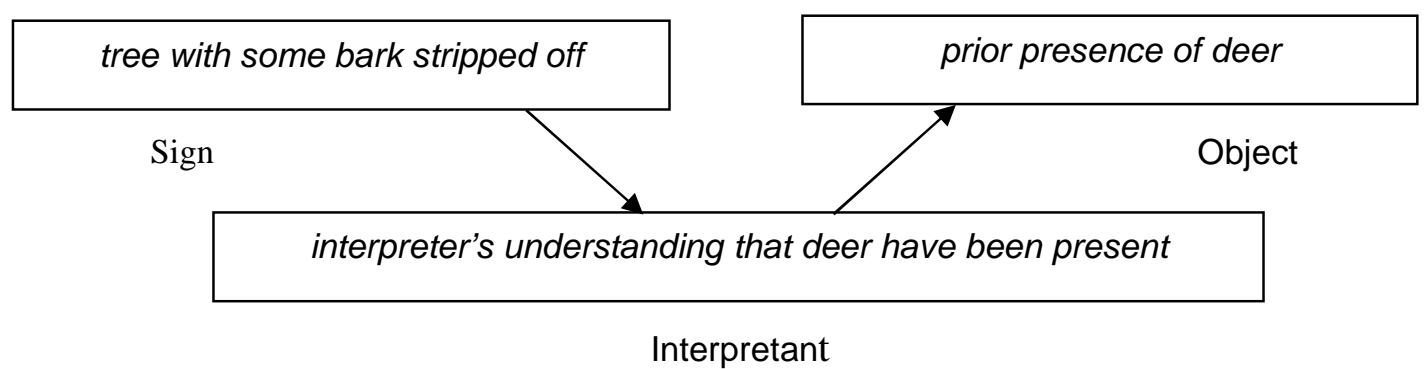

Figure. 1 Interpreting a sign

The stripped bark of tree, which is all that the interpreter can see, gives her or him further knowledge, namely knowledge that deer have been present because $\mathrm{s} / \mathrm{he}$ understands it is a sign of this prior presence. The sign thus brings the interpreter into cognitive contact with the deer (Malmkjaer, 2001, pp. 536-537). Lévi-Strauss starts from the assumption that the human mind is everywhere the same and cultures are different implementations of basic abstract logical properties of thinking which are shared by all humans and adapted to specific living conditions (Duranti, 1997, p. 33).

The issue then becomes the extent to which the same types of combinations or substitutions are found in a variety of different cultures. If they are found in historically unrelated societies, the anthropologist may see in these associations universal categories of human thought. In this method notions taken from linguistic theory can be used in cultural analysis because culture is understood as a system which communicates itself through social actors. Lévi-Strauss believed that is not people who communicate through myths, but myths communicate through people (Duranti, 1997, p. 35).

\section{METHODS}

This research is conducted with qualitative paradigm. Then, linguistic anthropology is used as the method to gain the data in the field of research. Duranti (1997) introduces linguistic anthropology as an interdisciplinary field which studies language as a cultural resource and speaking as a cultural practice. According to Héc (1979 quoted in Ilić, 2004, p. 3), it is usually what one first thinks of when talking about the relationship between language and culture. It studies language variations and use in relation to the cultural patterns and beliefs and relies heavily on theories, methods and findings of anthropology.

The data used in this study is a poem pepujian that the oral tradition of Cirebonese society. The data is obtained by the researcher from the speech community in various regions and the city of Cirebon regency directly. In this case, the researcher as the main instrument of research conduct each phase independently in the field. Thus, the data obtained were then analyzed according to the theory used. So finally this study led to the conclusion on issues that serve as the main topic of research.
3. RESULT DISCUSSION
In Cirebonese society, the time after the call to prayer(azan) before the obligatory prayers in congregation is often used to chant pepujian. Poetries sung in it typically use Cirebon language. There are also some that use it mixed shalawat poetry in Arabic.

Here are five poems pepujian in Cirebon language that used as research data.

\#1 dikentongi diazani ora teka 'called by azandoes not come'

iku wong bakal cilaka

'the people would be damned'

dawuh Nabi sekabeh umat

'The Prophet (Muhammad SAW) said to all people'

umat Islam aja tinggal salat

'Muslims do not leave prayer'

tinggal salat siksane berat

'leaving prayers punished weightly'

besuk ning alam akherat

'later in the hereafter'

sugih sawah sugih mobil

'rich of rice rich of car'

besuk mati tunggangane katil

'tomorrow death driving katil'

harta benda ora ngintil

'treasures do not participate'

sing ngintil amal secuil

'what participates a bit of charity'

\#2 eling-eling umat

'please remember all people' muslimin muslimat

'all of men and women muslim'

ayo kita salat berjamaah ....

'let us pray together ...'

iku kewajiban kita umat Islam

'it is our duty as the muslim'

kanggo bekal mengko

'for lunch later'

ning alam akhirat

'in the hereafter'

\#3 eman-eman temen

'how a pity' 
wong ganteng bli sembahyang

'handsome people do not pray'

Nabi Yusuf ganteng

'Prophet Yusuf is handsome'

ya gelem sembahnyang

'yes want to pray'

eman-eman temen

'how a pity'

wong sugih bli sembahnyang

'rich people do not pray'

Nabi Ayub sugih

'Prophet Ayub is rich'

ya gelem sembahyang

'yes want to pray'

\#4 ayo batur dulur

'let my friend and brother'

pada wudu toli dangdan

'keep wudhu then dressing'

mangkat tajug nglakoni kewajiban

'going to mosque perform the obligatory'

salat sunah aja pada ketinggalan

'extra prayer should not be left'

nonggoni imam enake bari pujian

'waiting for the priest delish while praising'

For the people of Cirebon, the lyrics four pepujian(\#1, \#2, \#3, and \#4) above contain the teachings of Islam in the aspect of worship. Especially prayers delivered as worship with the value exceeds the principal treasures of the world. In this case the Islamic doctrines of death, hell, the torment, world, fail, poor, and disobedient on one side will be in opposition to the values of life, heaven, the reward, hereafter, care, rich, and obedient on the other side. For more details can be seen in the table below.

Table 1. Islamic Doctrines in The Aspect of Worship Binary oppositions of Lévi-Strauss

\begin{tabular}{ll}
\hline Death & life \\
\hline Hell & heaven \\
\hline Torment & reward \\
\hline World & Hereafter \\
\hline Fail & Care \\
\hline Poor & Rich \\
\hline Disobedient & Obedient \\
\hline
\end{tabular}

\#5 duh Gusti, kula

'oh God, I'm'

sanes ahli surga

'not a heaven expert'

namung boten kiat

'but not strong at all'

mlebu ing neraka

'going to the hell'

duh Gusti, kula

'oh God, I'm'

nyuwun pangampura

'beg Your forgiveness'

sekatahe dosa

'of sins just as much'

ingkang sampun lewat

'which have passed'

As for the lyrics of pepujian (\#5) above contains about Islamic teachings on faith aspect. In this case, the conviction of a Muslim will be the arrival of the hereafter after a life in this world are the main ones. Just surrender to God will reward her/his deeds alone can finally add her/his belief. Islamic doctrines regarding heaven, hell, sin, reward, torture, forgiveness will always be present in tandem for human life. In the end, s/he will get only one of the two things that are in opposition. For more details can be seen in the table below.

Tabel. 2 Islamic Doctrines in The Aspect of Faith Binary oppositions of Lévi-Strauss

\begin{tabular}{ll}
\hline Heaven & Hell \\
\hline Reward & Sin \\
\hline Forgiveness & Torture \\
\hline
\end{tabular}

The main point, the values of Islam of course always be an ingredient in a variety of preaching discourse. Its presence vary according to the context. As in pepujian for example, presents a preaching discourse of worship and faith values. Both work together with depictions of the signs of Islamic teachings are substantial while sung before prayers began. The following figure is how to interpret pepujian.

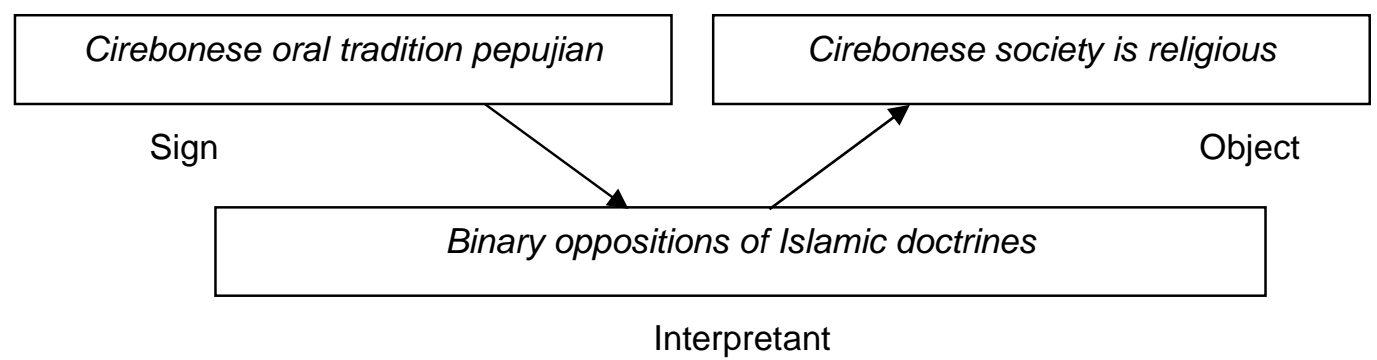

Figure. 2 Interpreting Pepujian 
Thus, the form of interpretation to whatever cultural forms subjectively be returned to any reader of the sign. Not always a matter that has been agreed must be followed. Opportunities to provide new and different interpretation of the existing ones remain open. Just how rationalize accordance with the facts and realities that exist in the culture of society stakeholders.

\section{CONCLUSION}

Pepujian as a medium of preaching using the signs of Islam in the realm of worship and faith in small rural tajug-tajug even urban mosques in Cirebon. In fact, there are Cirebonese people who claim not feel the "thrill" while listening the Islamic preaching that is not delivered to their language. Nonetheless, it seems to compliment the oral tradition still favored by those who are considered as the traditional muslims. In other words, the times and intellectuals bring modern muslim societies is to practice Islamic teachings subtance rather than merely rituals only. Thus was going on here, both an individual or society of traditional and modern muslims, they will always show the signs as indicators of their religiosity. Religiosity can be seen from such Islamic values heaven, hell, life, deathwhich is always sung with the language of Cirebon just before prayers.

\section{REFERENCES}

Backer, M. B. A. (2007). Semiotics: Signs and Meanings in Contemporary Dance in Malaysia. Journal of Arts and Discourse. Vol. 6: pp. 71-76.

Barker, C. (2004). The SAGE Dictionary of Cultural Studies. London: SAGE Publication Ltd.

Berger, A. A. (2014). Semiotics and Society. Symposium: Signs, Symbols, and Semiotics 51: pp. 22-26.

Darquennes, J. \& Vandenbussche, W. (2011). Language and Religion as A Sociolinguistics Field of Study: Some Introductory Notes. Sociolinguistics 25: pp. 1-11.

Duranti, A. (1997). Linguistic Anthropology. New York: Cambridge University Press.

Geertz, C. (1983). Local Knowledge: Further Essays in Interpretive Anthropology. New York: Basic Books, Inc.

Ilić, B. M. (2004). Language and Culture Studies Wonderland through The Linguistic Looking Glass. Linguistics and Literature. Vol. 3 (1): pp. 1-15

Keane, Webb. (1997). Religious Language. Annual Reviews Anthropology 26: pp. 47-71.

Malmkjaer, K. (2001). The Linguistics Encyclopedia. London: Routledge. 